\title{
The susceptibility of suckling lambs to zinc toxicity
}

\author{
BY N. T. DAVIES, H. S. SOLIMAN*, W. CORRIGALL \\ AND A. FLETT \\ Rowett Research Institute, Bucksburn, Aberdeen AB2 9SB
}

(Received 15 March 1977 - Accepted 21 March 1977)

\begin{abstract}
1. Suckling lambs maintained for 4 weeks on a milk-substitute diet containing $407 \mathrm{~g}$ Toprina yeast $/ \mathrm{kg}$ dry matter of diet exhibited poor growth, low appetite and extensive renal damage.

2. The batch of yeast used contained $2065 \mathrm{mg} \mathrm{zinc} / \mathrm{kg}$.

3. The kidneys of lambs offered a milk diet supplemented with the same $\mathrm{Zn}$ content as the yeast-fed diet $(32 \cdot 1 \mathrm{mg} \mathrm{Zn} / 1000 \mathrm{~kJ})$ were similarly affected.
\end{abstract}

The results reported in this paper concern the rapid development of gross kidney lesions in young lambs maintained on a milk-substitute diet using yeast as the sole protein source. Analysis of this particular batch of yeast showed it to contain an abnormally high zinc content and the results of a subsequent experiment in which lambs were offered a milk diet supplemented with the same high level of $\mathrm{Zn}$ strongly suggest that $\mathrm{Zn}$ was the toxic agent responsible. The purpose therefore of this current report is to bring to the readers' attention the dangers of high dietary $\mathrm{Zn}$ in suckling lambs.

\section{MATERIALS AND METHODS}

\section{Experiment 1}

Four lambs ( 2 male and 2 female; Suffolk $\times$ Finnish Landrace $\times$ Dorset poll) representing part of an experiment designed to evaluate the adequacy of a commercial yeast (Candida sp, Toprina; BP Proteins Ltd) as a protein source in milk substitute diets for suckling lambs, were offered from one week old a formula containing ( $\mathrm{g} / \mathrm{kg}$ dry weight) yeast, 407 ; lactose, 245; Methionine, 15; butter, 275; PEG 400 mono-oleate, 35; and vitamins and minerals to give similar contents to ewe's milk. These ingredients were thoroughly mixed with water in the ratio, $160 \mathrm{~g}$ dry weight: 1 l water to give a final energy content of $4184 \mathrm{~kJ} / \mathrm{kg}$ liquid diet. The liquid diet was offered to the lambs via an automatic feeder for 5 mins every $3 \mathrm{~h}$ in eight equal feeds and the amount adjusted daily so each lamb had access to $1046 \mathrm{~kJ}$ gross energy $/ \mathrm{kg}$ body-weight ${ }^{0.75}$ per $\mathrm{d}$.

After $35 \mathrm{~d}$ the lambs were killed and one kidney and a liver sample from each lamb were removed and stored at $-20^{\circ}$ for subsequent trace element analysis. The remaining kidney was immediately fixed in formol saline ( $40 \mathrm{~g}$ formaldehyde in 11 saline $(9 \mathrm{~g} \mathrm{NaCl} / \mathrm{l})$ ) before histological examination.

\section{Experiment 2}

Four male lambs of the same strain as described above were offered from one week old a liquid diet of reconstituted dried whole milk to give an energy content of $4184 \mathrm{~kJ} / \mathrm{kg}$ liquid diet. One lamb served as a control and was offered the milk diet only, while the remaining three were offered the milk diet supplemented with $\mathrm{Zn}$ (as $\mathrm{ZnSO}_{4} \cdot 7 \mathrm{H}_{2} \mathrm{O}$ ) to supply $32.1 \mathrm{mg} \mathrm{Zn} / 1000 \mathrm{~kJ}$. Lambs were bottle-fed three times a day so that they received $1046 \mathrm{~kJ} / \mathrm{kg}$ body-weight ${ }^{0.75}$ per d. After $33 \mathrm{~d}$ the control and two experimental lambs

* Present address: Department of Animal Production, Faculty of Agriculture, Aim Shams University, Cairo, Egypt. 
were killed while the remaining lamb was transferred to unsupplemented milk for a further $14 \mathrm{~d}$. Samples of liver and kidney were retained for trace element analysis and kidney samples fixed, as described above, for histological examination.

\section{Trace element analysis}

Diet and tissue samples were analysed for $\mathrm{Zn}$, copper, iron, lead and cadmium by atomic absorption spectrophotometry using a Varian Techtron AA5, after a wet ashing procedure (Davies \& Nightingale, 1975).

\section{Histological examination}

Fixed samples of kidney were sectioned on a microtome and stained in haematoxylin/eosin. Examination of the slides was carried out without prior reference to the animal's treatment.

\section{RESULTS AND DISCUSSION}

\section{Experiment 1}

Four lambs maintained on the diet containing 'Toprina' yeast from one particular batch exhibited, to varying degrees, low appetite and poor growth rates over a four-week trial period. Their average daily weight gains varied from 15.2 to $36.4 \mathrm{~g} / \mathrm{d}$ with a mean of $21 \cdot 2 \mathrm{~g} / \mathrm{d}$. Average daily feed intakes were highly variable ranging from $442 \cdot 2$ to $801 \cdot 2 \mathrm{~kJ} /$ $\mathrm{kg} \mathrm{W}^{0.75}$ per $\mathrm{d}$ with a mean of $550.6 \mathrm{~kJ} / \mathrm{kg} \mathrm{W}_{i^{\prime}}^{0.75}$ per $\mathrm{d}$. These values can be compared with growth rates of $150-160 \mathrm{~g} / \mathrm{d}$ and daily food intakes of $1046 \mathrm{~kJ} / \mathrm{kg} \mathrm{W}^{0.75}$ for lambs maintained under identical conditions on whole milk diets $(\mathrm{H}$. Soliman, unpublished observations).

Post-mortem examination revealed obvious lesions of the kidneys. They were enlarged and very pale. Histological examination gave similar findings in all, varying in extent. There was an increase of fibrous tissue particularly in the outer cortex, but also in linear areas among the straight tubules. Some glomeruli were atrophic and there were wide Bowman's spaces. Many of the tubules were dilated and tortuous. Occasional proteinaceous and some cellular casts were seen.

Renal damage is often associated with the ingestion of heavy metals such as $\mathrm{Pb}$ and $\mathrm{Cd}$ (reviewed by Bremner, 1974) and, since it was apparent that the severity of the renal damage was greater in the lambs that ate the most diet, it seemed possible that a heavymetal toxicity may have been responsible. Analysis of the Toprina yeast showed it to contain less than $0.02 \mathrm{mg} \mathrm{Cd} / \mathrm{kg}$ and less than $0.5 \mathrm{mg} \mathrm{Pb} / \mathrm{kg}$. However, it contained $2065 \mathrm{mg} \mathrm{Zn} / \mathrm{kg}$

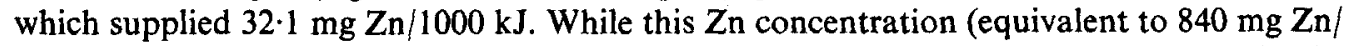
$\mathrm{kg}$ dry matter) was appreciably lower than that inducing $\mathrm{Zn}$ toxicity in post-weaning lambs (Ott, Smith, Harrington \& Beeson, 1966), analysis of the kidneys revealed that Zn concentrations in the cortices ranged from 2720 to $7943 \mathrm{mg} \mathrm{Zn} / \mathrm{kg}$ dry weight with a mean of $3887 \mathrm{mg} \mathrm{Zn} / \mathrm{kg}$ dry weight, and the severity of the lesions was clearly related to the cortical $\mathrm{Zn}$ contents. These kidney cortex $\mathrm{Zn}$ contents can be compared with 299 and $320 \mathrm{mg} \mathrm{Zn} / \mathrm{kg}$ dry weight for lambs of similar age maintained on a milk diet (Soliman, Davies \& Ørskov, unpublished observations).

\section{Experiment 2}

This experiment was designed to elucidate whether $\mathrm{Zn}$ was the toxic agent responsible for the kidney lesions. One lamb served as a control and was fed unsupplemented reconstituted dried milk while the three experimental lambs received milk supplemented with $\mathrm{ZnSO}_{4} \cdot 7 \mathrm{H}_{2} \mathrm{O}$ to supply the same $\mathrm{Zn}$ content as the yeast diet $(32 \cdot 1 \mathrm{mg} \mathrm{Zn} / 1000 \mathrm{~kJ})$.

Unlike the situation in Expt 1 the high dietary $\mathrm{Zn}$ content did not affect food intake since all animals consumed the $1046 \mathrm{~kJ} / \mathrm{kg} \mathrm{W}^{0.75}$ per $\mathrm{d}$ offered. Despite this the animals 
Table 1. Weights, percentage dry matter (DM), and zinc copper and iron contents ( $m g / k g$ DM) of kidneys from lambs fed basal milk diet for $33 d$ (636), zinc-supplemented milk for $33 d$ (634 and 635) and zinc-supplemented milk for $33 d$ followed by the basal milk diet for $14 d(633)$

$\begin{array}{clccccccccc}\begin{array}{c}\text { Lamb } \\ \text { no. }\end{array} & \text { Treatment } & \begin{array}{c}\text { wt } \\ (\mathrm{g})\end{array} & \% \text { DM } & \mathrm{Zn}_{\mathrm{Zn}} & \mathrm{Cu} & \mathrm{Fe} & \mathrm{Zn} & \mathrm{Cu} & \mathrm{Fe} \\ 636 & \text { Basal } & 17.3 & 18.4 & 136 & 24.8 & 292 & 95.0 & 15.6 & 149.0 \\ 634 & \text { Zn-supplemented } & 40.2 & 21.4 & 23900 & 149 & 44.6 & 3220 & 42.3 & 60.3 \\ 635 & \text { Zn-supplemented } & 45.9 & 19.9 & 19000 & 115 & 49.5 & 4790 & 37.4 & 69.7 \\ 633 & \begin{array}{c}\text { Zn-supplemented } \\ \text { then basal }\end{array} & 46.4 & 20.2 & 16200 & 73.8 & 54.2 & 4750 & 35.8 & 77.9\end{array}$

receiving the high $\mathrm{Zn}$ milk grew at average daily rates of $96 \cdot 9,96 \cdot 8$ and $81 \cdot 3 \mathrm{~g} / \mathrm{d}$ compared with $160 \mathrm{~g} / \mathrm{d}$ for the control. The lamb transferred from high $\mathrm{Zn}$ milk to the unsupplemented milk showed no improvement in its average daily weight gain.

Post-mortem examination of the three lambs which had consumed the high- $\mathrm{Zn}$ milk showed similar pathological changes to those observed in the yeast-fed lambs. The kidneys were enlarged and pale, whereas those from the control lamb appeared normal. Histological examination of the affected kidneys showed fibrous tissue increase, some glomerular atrophy and tubular distortion. Cells of the tubular epithelium had densely staining cytoplasm and pyknotic nuclei. Histological examination of kidneys from the control lamb revealed no specific lesions.

The weights, percentage dry matter and trace metal composition of the kidneys are shown in Table 1 . In all lambs which received high $\mathrm{Zn}$ milk the $\mathrm{Zn}$ content of the cortex was at least two orders of magnitude greater than that of the control. All affected animals showed elevated cortical $\mathrm{Cu}$ contents and substantial reductions in Fe contents, although the significance of these findings in relation to the renal damage cannot be assessed. Qualitatively similar although less marked changes in metal composition were seen in the medullary tissue. These findings do not indicate any substantial loss of $\mathrm{Zn}$ from the kidneys of lamb 633 over the $14 \mathrm{~d}$ period when it received unsupplemented milk.

The concentrations of $\mathrm{Zn}$ in the livers of the lambs receiving high $\mathrm{Zn}$ milk were elevated, being 2664, 2133 and $2311 \mathrm{mg} \mathrm{Zn/kg} \mathrm{dry} \mathrm{weight} \mathrm{respectively} \mathrm{for} \mathrm{lambs} \mathrm{633,} 634$ and $635 \mathrm{com}$ pared with $299 \mathrm{mg} \mathrm{Zn} / \mathrm{kg}$ dry weight for the control lamb (636). In contrast to the kidney, liver $\mathrm{Cu}$ contents were lower than the control being $39.0,156$ and $168 \mathrm{mg} \mathrm{Cu} / \mathrm{kg}$ dry weight for 633,634 and 635 respectively compared with $309 \mathrm{mg} \mathrm{Cu} / \mathrm{kg}$ dry weight for lamb 636 .

The cortical $\mathrm{Zn}$ contents of kidneys from these milk-fed animals were much higher than those of the lambs receiving the yeast diet. However, it is not possible to make any statements regarding differences in $\mathrm{Zn}$ availability from these two diets even though both groups of animals were offered diets containing the same concentration of $\mathrm{Zn}(32.1 \mathrm{mg}$ $\mathrm{Zn} / 1000 \mathrm{~kJ}$ ). The yeast-fed lambs never consumed all the diet that was offered to them in contrast to the milk-fed lambs. In addition the amount of food offered each day was adjusted according to the lambs' body-weight $\left(1046 \mathrm{~kJ} / \mathrm{kg} \mathrm{W}^{0.75}\right.$ per d) and the growth rates of the milk-fed lambs were approximately four times greater than those of the lambs receiving the yeast-based diet.

It has been stated that 'zinc is relatively non-toxic to birds and mammals' and 'that rats, pigs, poultry, sheep and cattle exhibit considerable tolerance to high intakes of zinc' (Underwood, 1971). Rats maintained on diets containing $2500 \mathrm{mg} \mathrm{Zn} / \mathrm{kg}$ exhibited no symptoms of $\mathrm{Zn}$ toxicity although at 5000 or $10000 \mathrm{mg} \mathrm{Zn} / \mathrm{kg}$ young rats exhibited anorexia, 
subnormal growth and at the higher level, heavy mortality (Heller \& Burke, 1927). These dietary $\mathrm{Zn}$ contents can be compared with $840 \mathrm{mg} \mathrm{Zn/kg}$ dry matter in the 'Toprina' based milk substitute used in these current experiments.

Young lambs appear to be less tolerant to high $\mathrm{Zn}$ intakes than rats. Ott et al. (1966) report that weaned lambs maintained on diets supplemented with $1500 \mathrm{mg} \mathrm{Zn} / \mathrm{kg}$ had reduced food consumption, weight gains and decreased feed conversion efficiency although no report was made of renal damage.

The results of this current study when compared with the work of Ott et al. (1966) suggest that the suckling lamb is considerably more susceptible to $\mathrm{Zn}$ toxicity than more mature ruminating animals. This may be due to greater absorption of dietary $\mathrm{Zn}$ since $\mathrm{Zn}$ absorption has been shown to be higher in the young of many species, compared with older animals. These examples include rats (Ballou \& Thompson, 1961) and cattle (Miller \& Cragle, 1965). However, in all of these studies the younger animals were fed rations of different composition from those fed to the more mature animals and it has not been established how much of the difference in $\mathrm{Zn}$ absorption was due to age and how much to alterations in dietary composition.

In conclusion it must be emphasized that in the first experiment yeast was used as the sole protein source and it is highly unlikely that this level of inclusion $(407 \mathrm{~g} / \mathrm{kg}$ dry diet) would ever be used in commercial practice. Secondly, the $\mathrm{Zn}$ content of the batch of 'Toprina' yeast used in this study at $2065 \mathrm{mg} \mathrm{Zn/kg}$ was abnormally high. Analysis of four different batches of 'Toprina' yeast produced at the same plant at about the same time contained from 889 to $1020 \mathrm{mg} \mathrm{Zn} / \mathrm{kg}$ and more recent batches consistently contain $500-600 \mathrm{mg} \mathrm{Zn} / \mathrm{kg}$. It has not yet been established whether inclusion of 'Toprina' yeast with these lower $\mathrm{Zn}$ contents in milk-substitute diets, or at lower levels of inclusion, would similarly produce deleterious effects in suckling animals.

The helpful discussions and advice of Drs E. R. Ørskov and C. F. Mills are gratefully acknowledged.

\section{REFERENCES}

Ballou, J. E. \& Thompson, R. C. (1961). Htth Phys. 6, 6.

Bremner, I. (1974). Q. Rev. Biophys. 7, 75.

Davies, N. T. \& Nightingale, R. (1975). Br. J. Nutr. 34, 243.

Heller, V. G. \& Burke, A. D. (1927). J. biol. Chem. 74, 85.

Miller, J. K. \& Cragle, R. G. (1965). J. Dairy Sci. 48, 370.

Ott, E. A., Smith, W. H., Harrington, R. B. \& Beeson, W. M. (1966). J. Anim. Sci. $25,414$.

Underwood, E. J. (1971). Trace Elements in Human and Animal Nutrition, 3rd edn. New York and London: Academic Press. 